інститут ДВНЗ «КНУ». - Кривий Ріг, 2012. - С. 30-33. 3. Кравцова І. А. Використання здоров' язбережувальної технології у процесі навчання - основна вимога до професійної компетентності вчителя початкової школи / І. А. Кравцова // Матеріали регіон. наук.практ. конф. [«Здоров’я дітей, підлітків, молоді та здоров’язберігаючі технології освіті»] (Кривий Ріг, 6 квітня 2012 р.) / М-во освіти і науки України, Криворізький педагогічний інститут. - Кривий Ріг: КПІ ДВНЗ «КНУ», 2012. - С. 12-15. 4. Марчик В. І. Холістична модель здоров'я в основі формування здорового способу життя / В. І. Марчик, T. В. Андріанов, В. С. Андріанов // Матеріали VII між. наук.-прак. конф. [«Реалізація здорового способу життя - сучасні підходи, присвячена 140-річчю від дня народження Івана Боберського»] (Дрогобич, 16-17 травня 2013)/ М-во освіти і науки України, Дрогобицький державний педагогічний університет імені Івана Франка. - Дрогобич: дДПУ, 2013. - С. 126-131.

\title{
ОЦІНКА ЗНАНЬ СТУДЕНТІВ В УМОВАХ КРЕДИТНО-МОДУЛЬНОЇ СИСТЕМИ НАВЧАННЯ
}

Антоненко I. I. Оцінка знань студентів в умовах кредитно-модульної системи навчання.

У статті розкрито особливості тестування за допомогою комп’ютера. Обгрунтована структура тестів для оцінки знань студентів в умовах кредитно-модульної системи навчання за Болонською системою. За результатами дослідження рекомендовано комп'ютерний метод оцінки знань студентів на базі програми «Асистент».

Ключові слова: оцінка знань, структура тестів, кредитно-модульна система навчання, комп'ютерне тестування, кількість запитань.

Антоненко И. И. Оценка знаний студентов в условиях кредитно-модульной системы обучения.

В статье раскрыты особенности тестирования с помощью компьютера. Обоснована структура тестов для оценки знаний студентов в условиях кредитно-модульного обучения согласно Болонской системы. По результатам исследования рекомендован компьютерный метод оценки знаний студентов на базе программы «Ассистент».

Ключевые слова: оценка знаний, структура тестов, кредитно-модульная система обучения, компьютерное тестирование, количество вопросов.

Antonenko I. I. The assessment of the students in credit-modular system.

The features of testing were revealed by computer. The structure tests were substantiated to assess student's knowledge in a credit-modular training in accordance with the Bologna system. As a result of research the computer method of estimation of knowledges of students is recommended on the base of the program «Assistant».

Key words: assessment of the knowledge, the structure of tests, the credit-modular system of training, computer testing, amount of questions.

Сучасна педагогічна наука накопичила чималий досвід використання інформаційних технологій у системі освіти $[1 ; 2 ; 3]$.

В умовах європейської інтеграції необхідно моделювати методи оцінки знань відповідно до Європейської кредитно-трансферної системи (ECTS). У навчальному 
процесі об'єктивна оцінка знань слугує основною умовою підвищення навчальної активності студентів. Кредитно-модульна система навчання грунтується на тестовому засобі організації оцінки знань студентів. Комп'ютерні тестові технології дозволяють індивідуалізувати перевірку знань студентів в однакових умовах, забезпечують об'єктивність отриманих результатів та значно полегшують роботу викладачів за рахунок автоматизації процесу контролю знань [3; 4]. Тому модернізація системи контролю знань студентів в умовах кредитно-модульної системи навчання за Болонською системою вимагає використання комп'ютерного тестування.

Meта cmammi: обгрунтування структури тестів в умовах кредитно-модульної системи навчання студентів та визначення необхідної кількості запитань.

Основними показниками якості тесту є диференційна здатність та економічність, тобто можливість виявляти встигаючих і невстигаючих студентів за мінімальних витрат часу і коштів на підготовку і проведення тестування.

Основним типом тестового завдання $є$ вибіркова відповідь множинного вибору (вибір із кількох варіантів). Перевагою тестів над іншими формами контролю знань $\epsilon$ наукова обгрунтованість. Надійність результатів контролю знань можна вважати задовільною, якщо ймовірність необгрунтованого отримання позитивної оцінки $\mathrm{P} \leq 0,01[5]$.

Імовірність угадування правильної відповіді $\mathrm{P}=1 / \mathrm{K}$, де $\mathrm{K}$ - число запропонованих відповідей на поставлене в тесті запитання.

Під час складання тестів важливим є розв'язання проблеми правдоподібності неправильних варіантів відповідей. Неправильні варіанти відповідей повинні бути правдоподібними зовнішньо i за змістом. Практика показує, що кількість правдоподібних відповідей не перевищує 4, тобто під час розроблення тестів необхідно приймати $K=4$. Значно ускладнює відгадування студентами правильних відповідей використання варіанта «правильної відповіді немає». Тож найбільш доцільною структурою під час побудови тестів потрібно вважати один варіант правильний, три неправильні, за наявності варіанта «правильної відповіді немає».

Під час перевірки знань за одномим питанням і чотирьма відповідями ймовірність вгадування правильної відповіді складає $\mathrm{P}=1 / 4=0,25$, що не забезпечує достатню надійність оцінки знань. Якщо перевірка знань здійснюється за кількома питаннями, то ймовірність вгадування всіх правильних відповідей дорівнює:

$$
\mathrm{P}_{\mathrm{i}}=\mathrm{P}_{1} \cdot \mathrm{P}_{2} \cdot \ldots \cdot \mathrm{P}_{\mathrm{i}}=(1 / \mathrm{K})^{\mathrm{i}} \quad[1] \text {, де } \mathrm{i}-\text { кількість запитань. }
$$

Тобто для надійного контролю знань необхідно виконати вимогу $(0,25)^{\mathrm{i}} \leq 0,01$. Нескладно розрахувати, що надійність отримання позитивної оцінки буде задовільною, якщо кількість запитань $\mathrm{i}=4$.

Із досвіду педагогічної практики відомо, що для задовільної оцінки необхідно знати 50\% від повного обсягу матеріалу, що вивчається [2]. Тоді для надійного отримання оцінки «відмінно» необхідно кількість питань збільшити до 8.

Під час визначення критеріїв оцінювання знань студентів на екзаменах викладачі керуються національною чотирибальною шкалою. Оцінка «незадовільно» виставляється студентам, які мають значні прогалини в знаннях і не можуть продовжувати навчання або приступати до професійної діяльності. Оцінка «задовільно» передбачена, коли прогалини в знаннях можуть бути усунені студентом в процесі навчання або праці. Оцінки «добре» заслуговує студент, який показав повне знання навчального матеріалу, але допущена незначна помилка. Оцінка «відмінно» свідчить про глибокі знання студента.

Успішність на заліках оцінюється за двобальною шкалою («зараховано», «не зараховано»). 
Національна оцінка в умовах кредитно-модульної системи навчання підлягає переведенню до шкали ECTS, яка має 7 оцінок: F- «незадовільно» 3 повторним вивченням курсу, FX - «незадовільно» 3 можливістю повторного складання, Е «достатньо» відповідає мінімальним критеріям, D - «задовільно» за наявності помилок і прогалин у знаннях, C- «добре» за досить повних знань, але наявності серйозної помилки, В - «дуже добре» за повних знань та незначних помилках, А - «відмінно»глибокі знання при незначній помилці.

В умовах кредитно-модульного навчання під час тестування обов'язково необхідно визначитися 3 оцінкою знань студентів у відсотках, або балах. В табл. 1 наведені рекомендації Криворізького педінституту ДВНЗ «Криворізький національний університет» для переведення кількості балів до оцінки ECTS.

Таблиця 1

Оцінка знань студентів в умовах кредитно-модульної системи навчання

\begin{tabular}{|c|c|c|c|}
\hline $\begin{array}{c}\text { За національною } \\
\text { шкалою (залік) }\end{array}$ & $\begin{array}{c}\text { За національною } \\
\text { шкалою } \\
\text { (екзамен) }\end{array}$ & За шкалою ECTS & $\begin{array}{c}\text { Визначення } \\
\text { оцінки в \% } \\
\text { (балах) }\end{array}$ \\
\hline \multirow{5}{*}{ ЗАРАХОВАНО } & відмінно & А (відмінно) & $90-100$ \\
\hline & \multirow{2}{*}{ добре } & В (дуже добре) & $80-89$ \\
\hline & & $\mathrm{C}$ (добре) & $70-79$ \\
\hline & \multirow{2}{*}{ задовільно } & D (задовільно) & $60-69$ \\
\hline & & Е (достатньо) & $50-59$ \\
\hline \multirow{2}{*}{$\begin{array}{c}\mathrm{HE} \\
\text { 3АРАХOBAHO }\end{array}$} & \multirow{2}{*}{ незадовільно } & FX (незадовільно) & $25-49$ \\
\hline & & F (незадовільно) & $1-24$ \\
\hline
\end{tabular}

Ураховуючи, що для забезпечення надійного результату тестування достатньо подати 8 запитань, тоді для отримання оцінки «А» необхідно дати 8 правильних відповідей, оцінки «В»- 7 правильних відповідей, оцінки «С»-6 правильних відповідей, оцінки «D»- 5 правильних відповідей, оцінки «Е» - 4 правильні відповіді, оцінки «FX»-2-3 правильні відповіді, оцінки «F» - 1 правильну відповідь.

Аналізуючи наявні контролюючі тестові програми, ми намагалися знайти 3-поміж них таку, яка б за мінімальної вартості й мінімального розміру дискового простору в постійній пам'яті комп'ютера забезпечувала б максимальну функціональність, широту налаштувань режимів роботи, простоту користування і створення тестів.

Комп’ютерна програма «Конструктор тестів» (автор П. Козловський) має такі можливості: використання необмеженого числа тем, питання можуть містити зображення, шкалу оцінок можна налаштувати від 5-бальної до 100-бальної системи, питання можливо ставити в довільному порядку з обмеженням відповіді за часом. Водночас вона має такі недоліки: великий розмір програми на установочному диску (317 Мб), програма потребує установки на комп'ютер і не може бути скопійованою 3 одного комп'ютера на інший, програмою не можна користуватися безкоштовно (вартість ліцензії 150 \$).

Значно зручніше здійснювати контроль знань студентів за допомогою програми «Asist 2» (Асистент 2). Під час запуску програми комп’ютер пропонує питання у випадковому порядку з обмеженням часу відповіді. Вона має переваги: малий розмір на диску (0,5 Мб), легко копіюється 3 одного комп'ютера на інший, має широке коло налаштувань і зручний інтерфейс, підтримує використання малюнків.

Зміст запитань охоплює практично весь курс і надає змогу об'єктивно оцінити рівень знань студентів 3 певної дисципліни як у груповій формі викладачем на заліку чи екзамені, так і самостійно для самоконтролю. 
Під час експериментального дослідження ця програма працювала стабільно і надійно. Спираючись на результати аналізу параметрів роботи контролюючих тестових програм, можна рекомендувати для оцінки знань студентів комп'ютерну програму Асистент 2. Виведення на екран комп'ютера запитань тесту у випадковому хаотичному порядку попереджує можливість знання відповідей заздалегідь. Математичний апарат програми автоматично виконує розрахунок результатів і виставляє оцінку. Наприкінці тестування на моніторі комп'ютера з'являється прізвище та ім'я студента, назва дисципліни (модуля), витрати часу та оцінка.

Отже, оцінювання знань за допомогою комп'ютера можна вважати найбільш прийнятним в умовах кредитно-модульної системи навчання студентів.

\section{Література}

1. Молибог А. Г. Программированное обучение / А. Г. Молибог. - М. : Высшая школа, 1967. - 197 с. 2. Завізена Н. Комп’ютеризація освіти з точки зору психологопедагогічного аспекту // Н. Завізена // Рідна школа. - 1999. - №11. - С. 62. 3. Стогний А. А. Основы компьютерной грамотности для преподавателей вузов и техникумов / А. А. Стогний. - К. : Вища школа, 1988. - 215 с. 4. Бугайов О. І. Концептуальні положення щодо розробки педагогічних програмних засобів із фізики / О. І. Бугайов // Комп’ютер у школі та сім’ї. - 2004. - № 8. - С. 13-14. 5. Ланіс В. Я. Підготовка студентів фізико-математичних факультетів до використання технічних

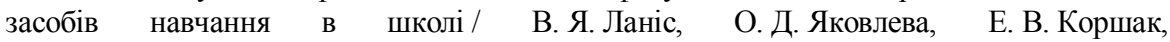
В. М. Таранченко. - К. : РНМКВСПО, 1979. - 24 с.

\section{Ріма Аронова}

\section{ПРОФЕСІЙНА КОМПЕТЕНТНІСТЬ МАЙБУТНІХ ФАХІВЦІВ ДОШКІЛЬНОГО ВИХОВАННЯ: СУТНІСТЬ, ЗМІСТ І СТРУКТУРА}

Аронова Р. С. Професійна компетентність майбутніх фахівців дошкільного виховання: сутність, зміст і структура.

Статтю присвячено проблемі професійної компетентності майбутніх фахівців дошкільного виховання. Розкрито сутність, зміст і структуру професійної компетентності фахівців дошкільного виховання, що дозволить їм ефективно виконувати професійні функції і завдання, а також забезпечить саморозвиток та самовдосконалення.

Ключові слова: професійна компетентність, майбутній фахівець, дошкільне виховання.

Аронова Р. С. Профессиональная компетентность будущих специалистов дошкольного воспитания: сущность, содержание и структура.

Статья посвящена проблеме профессиональной компетентности будущих специалистов дошкольного воспитания. Раскрыты сущность, содержание и структура профессиональной компетентности специалистов дошкольного воспитания, которая позволит им эффективно выполнять профессиональные функции и задания, а также обеспечит саморазвитие и самосовершенствование.

Ключевые слова: профессиональная компетентность, будущий специалист, дошкольное воспитание. 